\title{
Uranium Recycle by lon Exchange and Calcination - Summary of Process Development and Equipment Design
}

Savannah River National Laboratory

Westinghouse Savannah River Company

Publication Date: October 2005

Westinghouse Savannah River Company

Savannah River Site Aiken, SC 29808

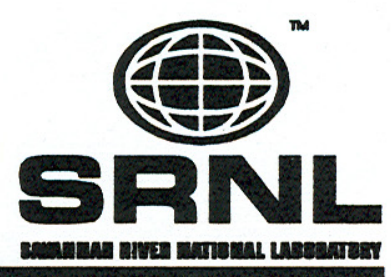

This document was prepared in connection with work done under Contract No. DE-AC09-96SR18500 with the U. S. Department of Energy 


\section{DISCLAIMER}

This report was prepared as an account of work sponsored by an agency of the United States Government. Neither the United States Government nor any agency thereof, nor any of their employees, makes any warranty, express or implied, or assumes any legal liability or responsibility for the accuracy, completeness, or usefulness of any information, apparatus, product, or process disclosed, or represents that its use would not infringe privately owned rights. Reference herein to any specific commercial product, process, or service by trade name, trademark, manufacturer, or otherwise does not necessarily constitute or imply its endorsement, recommendation, or favoring by the United States Government or any agency thereof. The views and opinions of authors expressed herein do not necessarily state or reflect those of the United States Government or any agency thereof. 
DOCUMENT: $\quad$ WSRC-TR-2005-00432, Rev. 0

TITLE: Uranium Recycle by Ion Exchange and Calcination - Summary of Process Development and Equipment Design

\section{APPROVALS}

D.J. Hathcock, Author SRNL-MATERIALS SCIENCE \& TECHNOLOGY

Materials Applications \& Process Technology Group

A.J. Duncan, Author SRNL-MATERIALS SCIENCE \& TECHNOLOGY

Materials Applications \& Process Technology Group

T.M. Adams, Technical Review

SRNL-MATERIALS SCIENCE \& TECHNOLOGY

Materials Applications \& Process Technology Group

R.L. Sindelar, Manager

SRNL-MATERIALS SCIENCE \& TECHNOLOGY

Materials Applications \& Process Technology Group

N.C. Iyer, Director

SRNL-MATERIALS SCIENCE \& TECHNOLOGY 


\section{Table of Contents}

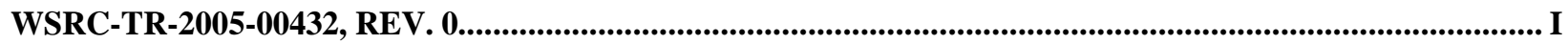

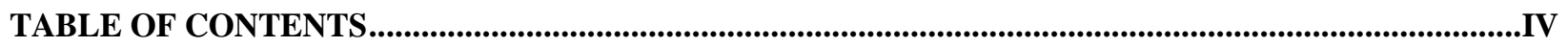

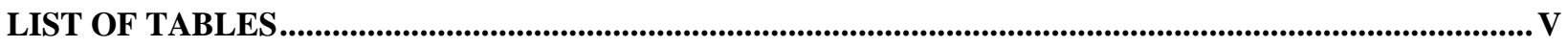

LIST OF FIGURES ...................................................................................................................................................

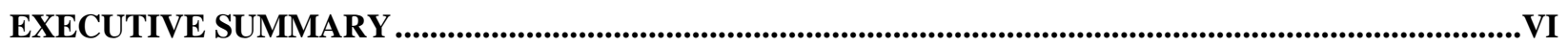

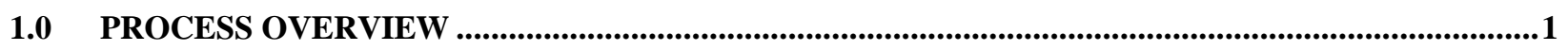

$1.1 \quad$ INTRODUCTION

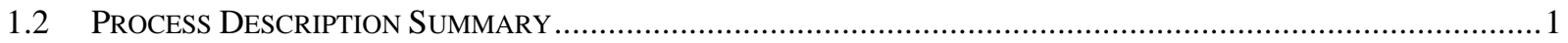

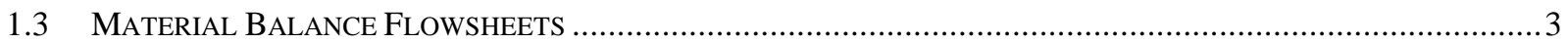

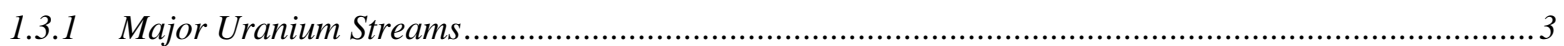

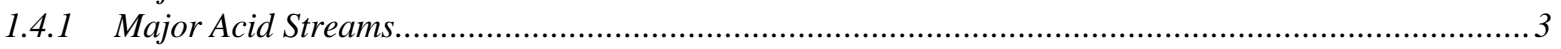

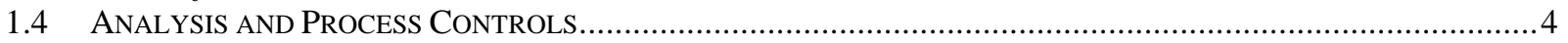

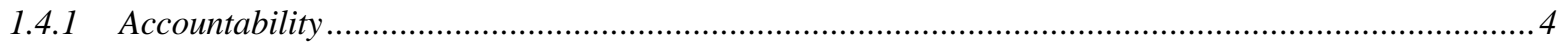

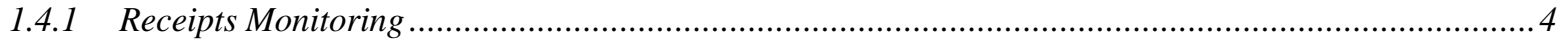

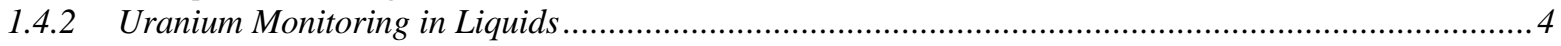

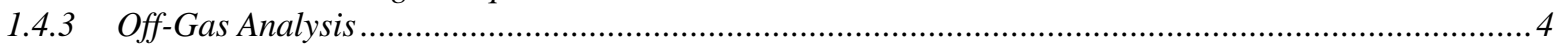

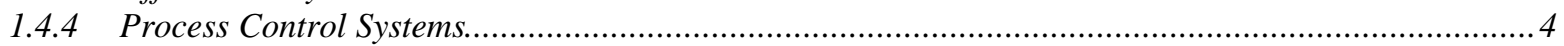

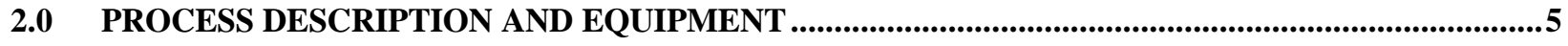

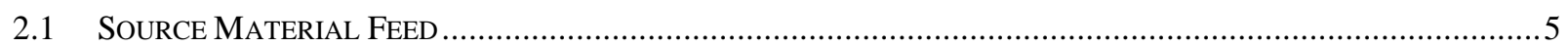

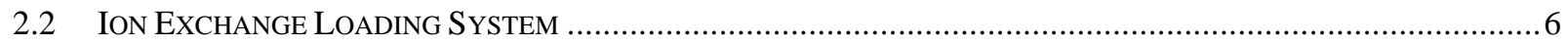

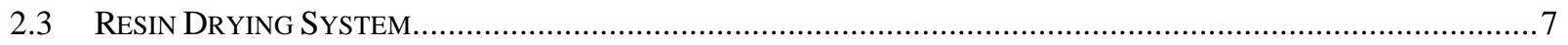

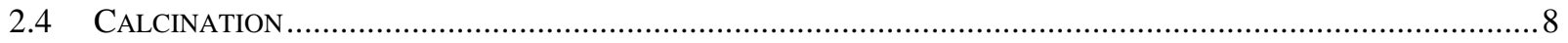

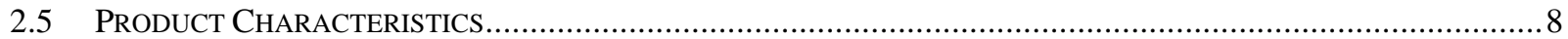

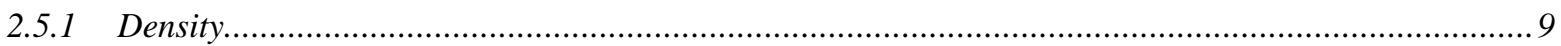

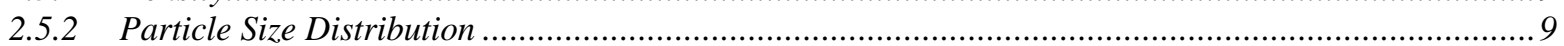

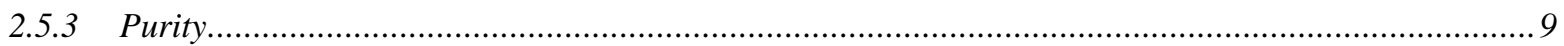

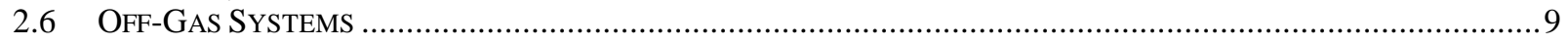

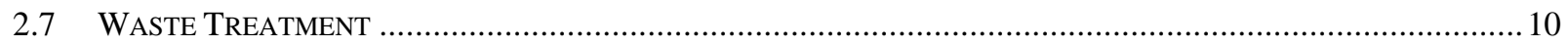

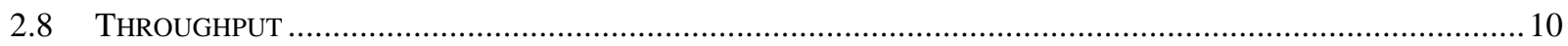

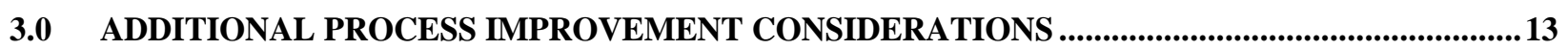

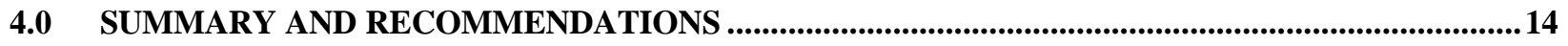

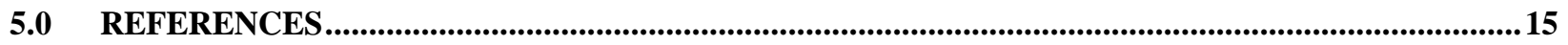


WSRC-TR-2005-00432, Rev. 0

Page $\mathrm{v}$ of vi

October 2005

\section{List of Tables}

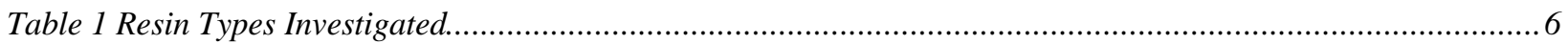

Table 2 Loading Dependent Calciner Off-Gas Composition (wt \%) ............................................................... 9

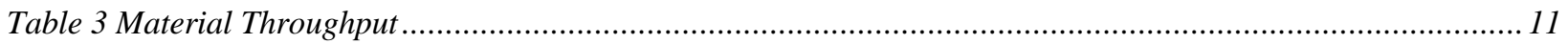

\section{List of Figures}

Figure 1 Conceptual Flowsheet for the Uranyl Nitrate Solution to $U_{3} O_{8}$ Powder Conversion Process......................2

Figure 2 Concept for Ion Exchange/Calcination Layout ........................................................................................5

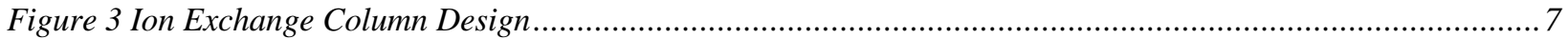

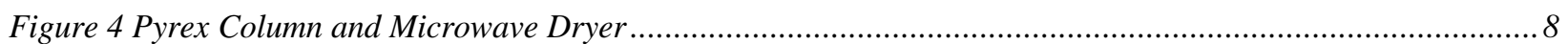

Figure 5 Uranium Process Throughput ................................................................................................... 12 


\section{Executive Summary}

Technical information for the process of recovery of uranium from uranyl nitrate hexahydrate solutions that was developed as part of the Onsite Uranium Recycle (OSUR) project conducted at the Savannah River Site in the 1980's is summarized. The process involves an ion-exchange process to load the uranyl species from solution onto a cation resin that is subsequently dried using a microwave oven, and then calcined using a rotary calciner to produce $\mathrm{U}_{3} \mathrm{O}_{8}$ powder.

The information in this report was compiled to support critical decisions for new facilities and processes at the Y-12 National Security Complex. The information includes a detailed description of the process and process equipment that were developed for the OSUR project including the technical bases for the materials selection and process conditions. Additional process considerations and recommendations to for a new-design facility are also provided. 


\subsection{PROCESS OVERVIEW}

\subsection{Introduction}

The process for the On-Site Uranium Recycle (OSUR) project was developed in the 1980's at the Savannah River Site (SRS) to recover on-site sources of uranium for fuel production. The process involved an ion exchange method to capture uranyl ions from uranyl nitrate hexahydrate solutions on macroporous cation exchange resin media. The loaded resin was dried using microwave drying, and calcined using a rotary calciner to form $\mathrm{U}_{3} \mathrm{O}_{8}$ powders, suitable for powder metallurgy fuel production. The conceptual design for a facility in H-Area at SRS (Onsite Uranium Recovery Facility) was completed in 1983 for two parallel production lines with a combined production capacity of 80 kilograms of uranium per day. The project was canceled following the installation but prior to full start-up operations of a pilotscale facility.

The process was demonstrated on bench- and pilot-scale systems. Process flow sheets and computer codes were developed to account for uranium in each process step within \pm 2 grams. The pilot-scale equipment has been discarded; the majority of the bench-scale equipment is available at the Savannah River National Laboratory, Materials Laboratory.

This report provides a compilation of the technical information and process requirements for the ionexchange/calcination technique that were developed in the OSUR project. Savannah River Site documents ${ }^{1-5}$ describing the technology development and design of the ion exchange and calcinations systems were reviewed to compile the information in this report.

This information is prepared for the Y-12 National Security Complex to support critical decisions for new facilities and processes at.Y-12.

\subsection{Process Description Summary}

The overall process is to convert uranyl nitrate solutions into $\mathrm{U}_{3} \mathrm{O}_{8}$ powder. The process includes four major steps:

- Feed Preparation;

- Resin Loading;

- Resin Drying; and

- Calcination

Resin and water are mixed for transfer feed as slurry into the resin column. Diluted uranyl nitrate solutions are then fed into the fixed bed of macroporous cation exchange resin. The resin slurry loaded with uranium is then fed into a drying oven. The dry resin is then fed into a calcining furnace. The transfer process includes liquids, slurries, and dry powders that are transferred hydraulically and pneumatically. Off-gasses and liquids are treated to minimize the volume of wastes and maximize the recycle in the process streams. Figure 1 provides a sketch of the overall process. 


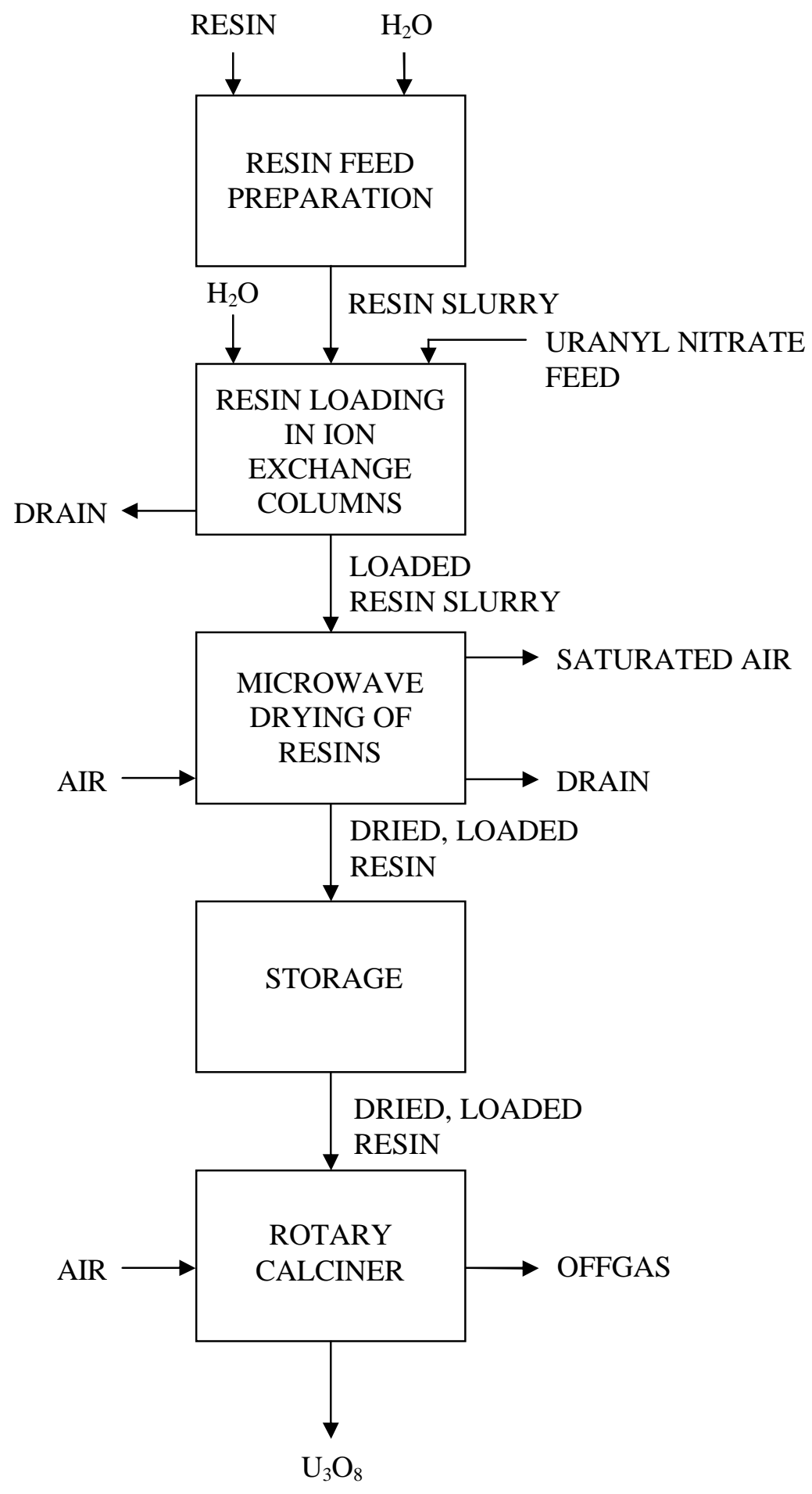

Figure 1 Conceptual Flowsheet for the Uranyl Nitrate Solution to $\mathrm{U}_{3} \mathrm{O}_{8}$ Powder Conversion Process 


\subsection{Material Balance Flowsheets}

The information in the following sections is a summary of the information contained in chapter 8 of reference 1 that has been generalized to material type. Specific material balance equations and process solutions for the full-scale facility are described in the original reference.

\subsubsection{Major Uranium Streams}

\section{Stream 1, Solids Feed}

Uranium solids are dissolved in concentrated nitric acid solution in five 3-kg batches per day. The resulting solution is $3.4 \mathrm{M}$ acid and contains $558 \mathrm{gU} / \mathrm{L}$, though the acidity can depend on feed type. Existing uranyl nitrate stock can also be used as feedstock.

\section{Stream 2, Dilute Nitrate Preparation/EU Blending}

After dilution and cooling in a holding tank the solution is $1.58 \mathrm{M}$ acid $250 \mathrm{gU} / \mathrm{L}$. The solution is then diluted again by $30: 1$ eduction to $8 \mathrm{gU} / \mathrm{L}$. The dilute nitrate solution and $\mathrm{EU}(8 \mathrm{gU} / \mathrm{L}, 0.15 \mathrm{M}$ acid) are then fed to the blending/feed tank and combined.

\section{Stream 3, Ion Exchange Column Feed}

The blended dilute nitrate/EU stream $(0.13 \mathrm{M}$ acid $)$ is fed to the ion exchange column $\left(1 \mathrm{ft}^{3}\right.$ settled volume). The columns are assumed to be loaded with $170 \mathrm{gU} / \mathrm{L}$ of settled resin volume $(28.32 \mathrm{~L})$, yielding $4.81 \mathrm{kgU}$ per column, though this loading level is based on a $0.15 \mathrm{M}$ acid feed.

\section{Stream 4, Loaded Resin Transfer and Drying}

The loaded resin is transferred, as a slurry, in equal parts to two drying ovens using $0.5 \mathrm{gpm}$ transfer water. The water content of the resin is reduced to $32 \mathrm{wt} \%$ by drainage and heated air drying, and the resin is then further dried to $15 \mathrm{wt} \%$ water using microwave heating.

\section{Stream 5, Dried Resin Calcination}

The dry resin is calcined in 10:1 mass ratio of air to dried resin resulting in volatilization of the resin and conversion of the ions to $\mathrm{U}_{3} \mathrm{O}_{8}$ powder. Acceptable oxide density should be in the 1.5 $\mathrm{g} / \mathrm{cc}$ to $4 \mathrm{~g} / \mathrm{cc}$ range.

\subsubsection{Major Acid Streams}

\section{Stream 6, Dissolver Nitric Acid Feed}

Each $3-\mathrm{kg}$ batch of solids requires $5.4 \mathrm{~L}$ of $50 \%$ nitric acid to the dissolver.

\section{Stream 7, Column Wash Water}

The resin bed is washed with 3 column volumes $(99 \mathrm{~L})$ of water. The water is sent through the second column to remove any entrained uranium.

\section{Stream 8, Effluent Stream}

Drain, condenser, and column effluent water are sent to a contaminated water holding tank for treatment, evaporation and/or recycle. 


\subsection{Analysis and Process Controls}

\subsubsection{Accountability}

Operators must be able to able to track U-235 movement through the process and localize any inventory discrepancies in as close to real-time as possible. Direct measurement of uranium content whenever material is divided, combined, or changed in chemical form was be the preferred method of tracking material. Accountability relied on a variety of measurement methods from non-destructive assays to laboratory testing of the material.

This process was ideal for accountability of U-235 since it was relatively easy to stop any step along the way for complete accountability of all material. During each major operation the content of the stream could be measured before and after the operation thus ensuring quick localization of any inventory differences.

\subsubsection{Receipts Monitoring}

Material received at the facility was to have been immediately be assayed for U-235 content and total uranium weight to determine any differences between received and expected material. Initial tests of received material were to be followed up by full laboratory analysis. Gamma spectroscopy was to be used to quickly determine both enrichment and density of received material by monitoring the spectra of both U-235 and U-238. For fuel tubes this type of analysis had resolved density and enrichment variations of $<1 \%$ and $<0.6 \%$ respectively with a $2000 \mathrm{sec}$ counting time. Faster turnaround would be achieved for larger or more concentrated uranium samples.

\subsubsection{Uranium Monitoring in Liquids}

Since a significant portion of the process uses quantities of dissolved uranium, it is important from an effluent, accountability, and process control standpoint to monitor the concentration in the liquid phase at all times. In order to maximize loading, the ion exchange columns was fed uranyl nitrate past breakthrough until the effluent has the same concentration as the original feed stream. The effluent of the first column, after the column is completely loaded, would have a concentration of uranium of $6000 \mathrm{ppm}$ by weight while being fed to the second column (See Figure 1-2). After passing through the second column, effluent went through a third column on the way to wastewater holding/processing. Using an optical spectrophotometer, the concentration of uranium in solution can be measured on-line during the process. This equipment can be interfaced to accountability and process control systems for real-time monitoring and control.

\subsubsection{Off-Gas Analysis}

Though process conditions were optimized to minimize off-gases, analysis of $\mathrm{CO}, \mathrm{CO}_{2}$, and $\mathrm{SO}_{2}$ off-gases would have been accomplished using on-line infrared analyzers that can also be tied into process monitoring and control systems.

\subsubsection{Process Control Systems}

The process was controlled through integration of sensing and individual equipment control systems with a centralized control and accountability system. Such centralization not only allowed flexibility to adjust parameters when special feeds or campaigns were being run, but also allowed accountability of the Special Nuclear Material to be monitored at each stage of production. Any discrepancy between material 
balance between one unit operation and the next could thus have been quickly detected and localized. Integration into a central system also increased automated operation, decreases operator exposure, and decreased the possibility of human error.

\subsection{PROCESS DESCRIPTION AND EQUIPMENT}

Technical information for the ion exchange/calcination process to recover uranium from uranyl nitrate solutions and produce $\mathrm{U}_{3} \mathrm{O}_{8}$ solids is described in detail. The conditions, concentrations, and quantities are specific to the design of the OSUR project with a yield $80 \mathrm{~kg}$ of uranium per day. Uranium enrichment levels for the source material feed and end product are not important to the chemical process and will not be cited.

A schematic of the facility layout is shown in Figure 2.

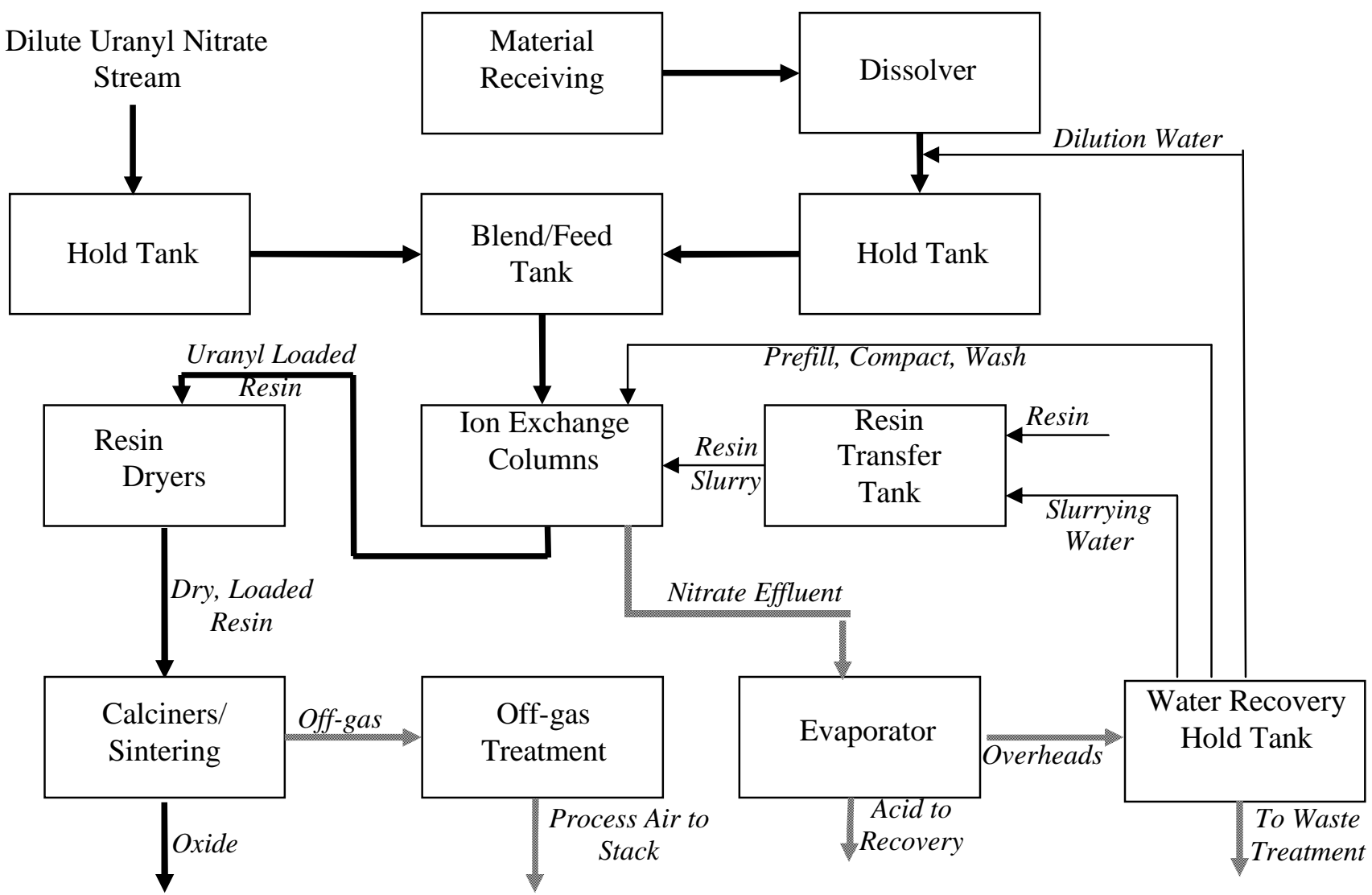

Figure 2 Concept for Ion Exchange/Calcination Layout

\subsection{Source Material Feed}

The dilute uranyl nitrate feed, from on-site processes, for the ion exchange process is dilute ( $8 \mathrm{gU} / \mathrm{L})$ uranyl nitrate solution that is $0.08 \mathrm{M}$ acid. The primary feedstock anticipated in initial OSUR process development included solid oxides that would have to be dissolved in nitric acid and diluted/blended as outlined in Section 1.3.1. Uranyl nitrate hexahydrate feed material can be dissolved in hot water and handled identically to the dilute nitrate stream. Feeds of different enrichment level must be blended to 
reach the appropriate feed level. The dissolver system must be nitric acid resistant and be able to withstand anticipated feed material impurities and be critically safe.

After dissolution the material would be fed to an accountability holding tank (allowing continuous dissolver operation) where isotopic levels, uranium content, and liquid volume measurements can be made before transfer to the nitrate holding tank. In transit to the nitrate holding tank the solution is diluted 30:1 by eduction, rendering the liquid critically safe in any geometry. The material is then fed to a blending tank to produce a liquid of uniform isotope content before being fed to the ion exchange columns.

\subsection{Ion Exchange Loading System}

Commercial ion exchange resin is used to remove the uranium from the dilute feed stream. The resin is a strong acid, macroporous sulfonated, cation exchange resin. A resin with particle diameters with a range of 140 to $420 \mu \mathrm{m}$ was desired for the process since the resin size controls the $\mathrm{U}_{3} \mathrm{O}_{8}$ powder size produced upon calcinations of the resin. The candidate resin, AG-MP-50, has the smallest particle size distribution (149 to $297 \mu \mathrm{m})$ of the alternative resins considered. Several alternative resin candidates were investigated during process development and are listed in Table 1. Two banks of three stainless steel resin columns, 6-inch diameter and approximately 6-foot tall were recommended in the OSUR design (see Figure 3 Ion Exchange Column Design).

Table 1 Resin Types Investigated

\begin{tabular}{|l|l|l|}
\hline \multicolumn{1}{|c|}{ Resin Name } & \multicolumn{1}{|c|}{ Composition } & \multicolumn{1}{c|}{ Characteristics } \\
\hline AG MP-50 & $\mathrm{C}_{8.8} \mathrm{H}_{8.8} \cdot \mathrm{HSO}_{3}$ & $\begin{array}{l}\text { Macroporous with 100 nm pores. } \\
\text { Exchange capacity of 1.7 meq/L } \\
\text { for resin with 50\% water }\end{array}$ \\
\hline Bio-Rex 70 & Carboxylate & $\begin{array}{l}\text { Macroreticular weak cation } \\
\text { exchanger. Exchange capacity of } \\
2.4 \text { eq/L }\end{array}$ \\
\hline Bayer & Phenolic & Exchange capacity of 2.2 eq/L \\
\hline
\end{tabular}




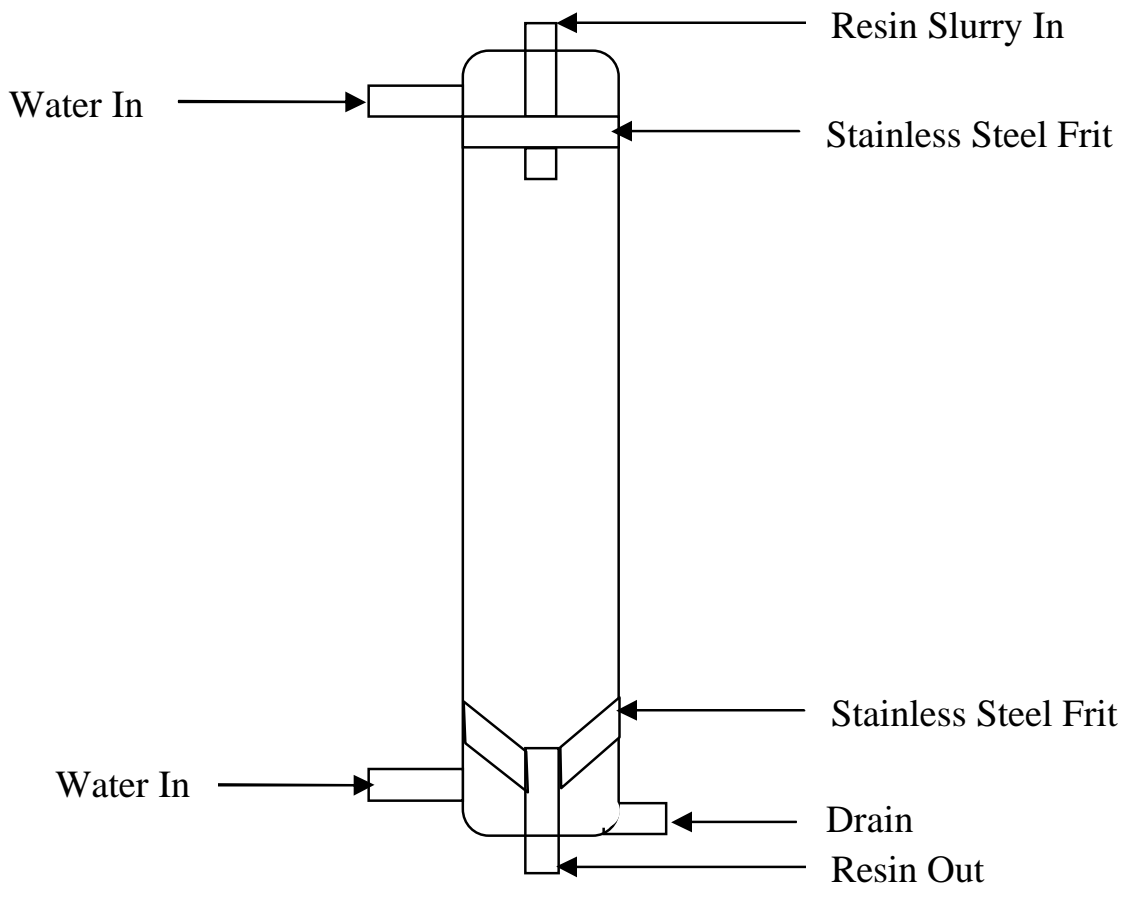

Figure 3 Ion Exchange Column Design

Each column is prefilled with water to provide a medium for the resin to suspend and settle uniformly. The resin feed tank is filled with a preweighed 0.83 -cubic foot $(23.5 \mathrm{~L})$ charge of resin that fills a 1 cubic foot volume or $86 \%$ of column when settled in a single ion exchange column. The feed tank is pressurized to $10-20$ psi and a resin slurry is hydraulically fed into the ion exchange column. The slurry enters through the top of the column, is suspended against a stainless steel frit filter at the bottom of the column, and is allowed to settle.

Methods to transfer resin into and out of the ion exchange columns as a slurry with the AG_MP-50 resin were investigated by experimentation..$^{5}$ Optimum transfer (through the $1 / 2$ " test tubing; the prototype tubing is 1") was achieved at low flowrates $(\sim 0.5 \mathrm{gpm})$ of water conveying the resin. It was observed that higher transfer rates led to line pluggage, and that lower rates are effective to maintain clear lines after transfer without using excessive process water.

\subsection{Resin Drying System}

Drying of the loaded resin involves several substeps. The resin column will be transferred to a Pyrex cylinder with $200 \mu \mathrm{m}$ glass filters at the top and bottom (see Figure 4). The column will be drained of excess water and reduced to $\sim 50 \mathrm{wt} \%$ by forcing room temperature air from the upper column frit through the bed to that mechanically carries off interstitial water.

Microwave drying would dry a 6-inch diameter, 35.6 inch long bed of resin from $50 \%$ wt $\%$ moisture to $15 \%$ within 1 hour. The degree of dryness is measured by a hygrometer in the outlet gas stream. Air that carries off water from the dryer is preheated to $70^{\circ} \mathrm{C}$ before it is introduced to the dryer. The microware power $(6 \mathrm{~kW})$ is sufficient to remove roughly two-thirds of the water in the loaded resin. The dried resin is free-flowing and can be transferred pneumatically to the calciner. 
The dried resin in transferred to a central hopper below the drying units and then subsequently transferred to storage bins prior to the calcination step.

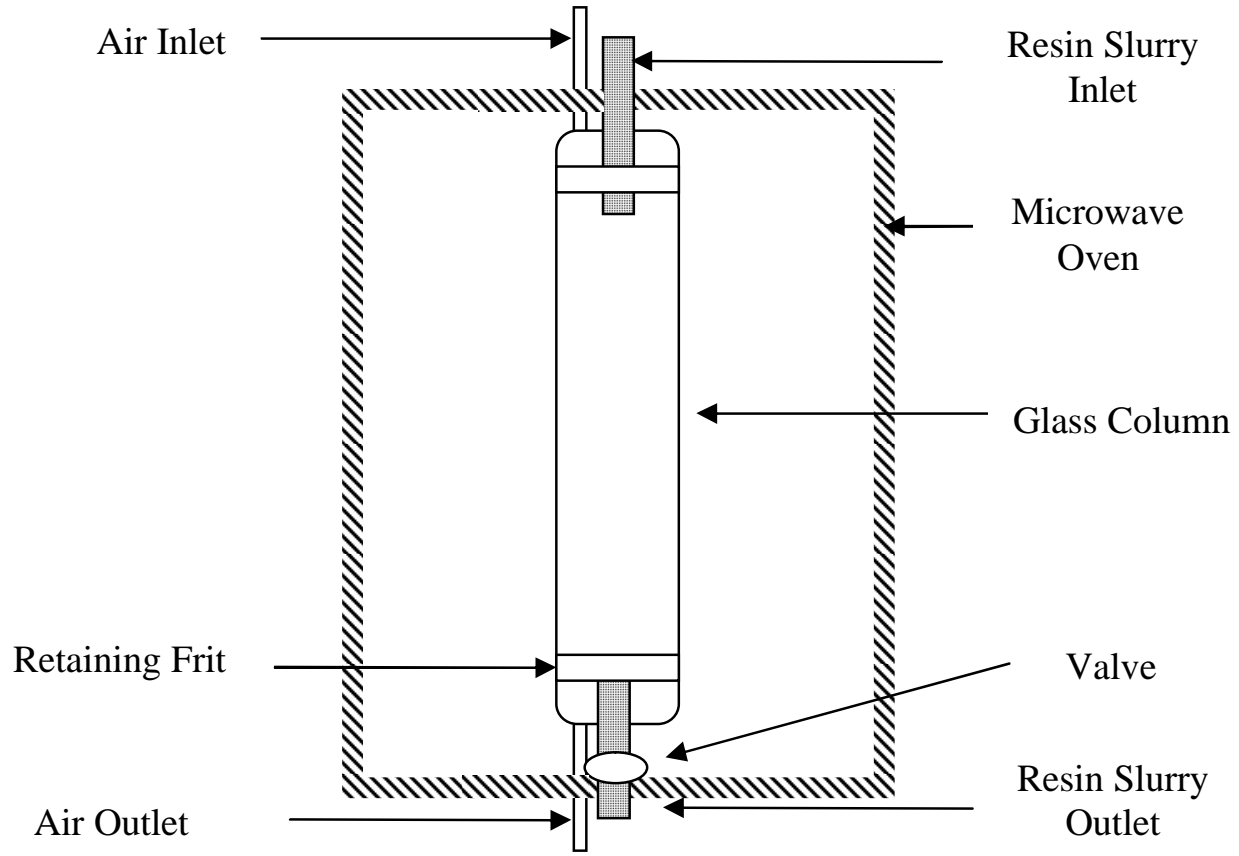

Figure 4 Pyrex Column and Microwave Dryer

\subsection{Calcination}

The dried resin is converted to $\mathrm{U}_{3} \mathrm{O}_{8}$ powder in rotary calciners. The Onsite Uranium Recycle Facility was planned to contain six rotary calciners, three each of the two processing lines. Each calciner would be 6" in diameter by 14 ' long.

Approximately 1-liter increments of dried resin are gravity-fed into vibratory feeders. These feeders discharge resin into an electrically-heated calciner at $0.04 \mathrm{~kg} / \mathrm{min}$.

The calcination process involves combustion gas flowing counter-current to the solids flow in the calciner. Loaded resin is auger fed to the calciner near the "high" end of the tube, and the uranium oxide combustion product drops out the "low"end. The tube has a 1/8" per foot slope.

Calcination achieves four goals: 1) resin material is burned, leaving only the uranium that was loaded on it during ion exchange; 2) the $\mathrm{UO}_{2}$ is converted to $\mathrm{U}_{3} \mathrm{O}_{8} ; 3$ ) the solids achieve a large size reduction to oxide of about $4.0 \mathrm{~g} / \mathrm{cc}$ density; and 4) the $\mathrm{U}_{3} \mathrm{O}_{8}$ is of size distribution controlled by the resin. If the spread and center of the oxide particle size distribution are not major drivers, the resin used could be varied.

\subsection{Product Characteristics}

The OSUR process was to provide $\mathrm{U}_{3} \mathrm{O}_{8}$ that would be a fuel feed for the SRS production reactor fuel using the Powder Metallurgy process. As such, physical characteristics such as product purity, particle size distribution, and oxide density were important. 


\subsubsection{Density}

The density of the oxides made in the rotary calciner was approximately $1.7 \mathrm{~g} / \mathrm{cc}$. This density was too low for the suggested range of 2.9 to $2.3 \mathrm{~g} / \mathrm{cc}$. The density is strongly affected by the oxygen content in burning in the calciner. Burning with too much oxygen gives a porous, low density oxide. Burning with too little oxygen does not completely burn the resin. Semiworks tests have shown that optimum conversion and product density are achieved when air flow to the calciner is $85 \%$ of the stoichiometric amount (120 SCF per $\mathrm{kg}$ of fully loaded resin feed) required for complete combustion of the resin yielding $\mathrm{U}_{3} \mathrm{O}_{8}, \mathrm{SO}_{2}, \mathrm{CO}_{2}$, and water as products. Resin was fed into the system at a rate of $4.3 \mathrm{liters} / \mathrm{h}$ for five hours. Oxide produced under these conditions was completely converted and had a bulk density of $\sim 2.4 \mathrm{~g} / \mathrm{cc}$. ${ }^{6}$ Air for combustion is preheated to $500^{\circ}-800^{\circ} \mathrm{C}$ before it is fed to the calciner. In the Onsite Uranium Recovery Facility, a single 100 SCFM fan was to supply air to all six calciners.

\subsubsection{Particle Size Distribution}

The oxide particle size distribution can be controlled by varying the mesh size of the ion exchange resin. In the case of the OSUR candidate material AG MP-50, particles with an average size of $37 \mu \mathrm{m}$ and 86 $\mu \mathrm{m}$ were produced using 200-400 mesh and 50-100 mesh respectively. Size ranges on the order of $20 \mu \mathrm{m}$ were obtained using $200-400$ mesh resin and $50 \mu \mathrm{m}$ for $50-100$ mesh resin in batch calcinations studies. The granular nature of the oxide product was found to be beneficial for use in the powder metallurgy process. Oxide particle size was optimized to mix well with aluminum powders used in the powder metallurgy process

\subsubsection{Purity}

Oxide particles produced using the OSUR process were compared with standard oxide samples and found to be chemically very similar and well within the material specifications. Both the standard and OSUR oxides were also compared in fuel tube extrusion tests and found to behave identically. Calcining of sulfonated ion exchange resin did not increase the sulfur content of the oxides.

\subsection{Off-Gas Systems}

Off-gases are generated in dissolving, drying, and calcining. The calciner gases contain oxides of the resin. The vapors from the feed uranium material preparation and from the drying step are dominated by air, water vapor, and less than $500 \mathrm{lb} /$ year of $\mathrm{NO}_{\mathrm{x}}$.

The ion exchange resin is a styrene-based polymer that contains sulfate groups and bound water. Combustion gases are dominated by carbon dioxide, water vapor, and sulfur dioxide and trioxide. Calciner off-gas also contains fine oxide particles that are entrained by the combustion gas. Entrained particles of unburned resin may also be collected during improper calciner operation; these particles are recycled as new calciner feed. Table 2 contains a detailed listing of the composition of the calciner offgas.

Table 2 Loading Dependent Calciner Off-Gas Composition (wt \%)

\begin{tabular}{|c|c|c|c|}
\hline Off-gas Component & $\mathbf{2 2 0} \mathbf{~ k g ~ U / L}$ & $\mathbf{1 7 0 ~} \mathbf{~ k g ~ U / L}$ & $\mathbf{1 4 6 ~ k g ~ U / L ~}$ \\
\hline $\mathrm{N}_{2}$ & 71.0 & 70.4 & 70.4 \\
\hline $\mathrm{O}_{2}$ & 13.4 & 13.4 & 12.1 \\
\hline $\mathrm{CO}_{2}$ & 9.4 & 9.3 & 10.8 \\
\hline $\mathrm{H}_{2} \mathrm{O}$ & 3.3 & 4.1 & 3.7 \\
\hline $\mathrm{SO}_{2}$ & 1.6 & 1.5 & 1.8 \\
\hline $\mathrm{Ar}$ & 1.2 & 1.2 & 1.2 \\
\hline Excess Calciner Oxygen & $162 \%$ & $164 \%$ & $127 \%$ \\
\hline
\end{tabular}


Each of the two lines in the Onsite Uranium Recycle Facility would have an off-gas processing line to cool, scrub, and filter the off-gas. The off-gas processing line contains:

- Spray chamber,

- Condenser,

- Scrub liquor tank,

- Circulating pump,

- Purge pump,

- Caustic venturi scrubber,

- Reservoir,

- Heater, and

- HEPA filters

\subsection{Waste Treatment}

Off-gases, containing predominately species listed in Table 2 , are first cooled to $100{ }^{\circ} \mathrm{C}$ with water spray. The cooled $40{ }^{\circ} \mathrm{C}$ water is then sent to a venturi scrubber. At lower temperature the solubility of $\mathrm{SO}_{2}$ in water increases and much of the $\mathrm{SO}_{3}, \mathrm{SO}_{2}, \mathrm{NO}_{x}$, and $\mathrm{CO}_{2}$ will be dissolved in the water spray. The spray water will be recycled, but replenished as needed to avoid particulate buildup. The venturi scrubber helps remove soluble species before the gas is exhausted to the building stack. At equilibrium 812 liters/day of water would be needed to completely remove the $\mathrm{SO}_{2}$ from an OSUR plant processing $48 \mathrm{~kg}$ of uranium a day. Sodium hydroxide could be added to the scrubber to increase efficiency. The scrubbing solution would remove a minimum of $99 \%$ of the $\mathrm{U}_{3} \mathrm{O}_{8}$ fines entrained and present in the off-gas stream.

Column effluent is combined with other process streams and evaporated. The resulting potentially contaminated water overheads are recycled and reused in-process. Uranium concentration in the column effluent is normally below $1 \mathrm{ppm}$ and much lower in the overhead condensate of the evaporators. The evaporator bottoms carry a much larger concentration of uranium as well as fission products carried along in the process. The partitioning of higher concentrations of contaminating species in the bottoms prevents buildup of these species in the recycled process water. Excess process water was handled by onsite processing facilities. If such facilities were not available they would have to be designed. Scrap and HEPA filters were to be processed for uranium recovery and the effluent handled by the Defense Waste Processing Facility.

\subsection{Throughput}

The quantities detailed in Table 3 represent process throughputs calculated in the original OSUR design using one dissolver tank and processing line. In the original design, a recycled dilute uranyl nitrate stream from a Canyon was used to make up the enrichment and uranium concentration of the feed solution to a predetermined recipe. A similar recycle stream may be used for new designs, or the feed supplied solely from the dissolver. The impact of such changes to the process could be thoroughly investigated on the bench scale using equipment at the Savannah River National Laboratory, Materials Laboratory. The average daily throughput of the facility is $48.70 \mathrm{~kg} \mathrm{U}$ per process line, the average yearly output of the facility is 16 metric tons $U$ per process line assuming 4-shift 7-day operation. Outlined in Figure 5 is a simplified version of the uranium movement through each unit process. If the oxide is sintered in a separate step from calcination, it is assumed $4 \%$ of the oxide would become entrained with the calciner off-gas stream. This loss may be recovered later in the process and the recycled solids added to the dissolver feed. The complete material balance is available in the original reference. ${ }^{1}$ 
Table 3 Material Throughput

\begin{tabular}{|c|c|c|c|c|c|c|c|c|c|}
\hline & $\begin{array}{l}\text { Solids to } \\
\text { Dissolver }\end{array}$ & $\begin{array}{c}\text { Conc. } \\
\text { Nitric to } \\
\text { Dissolver }\end{array}$ & $\begin{array}{c}\text { Dissolver } \\
\text { Dilute } \\
\text { Nitrate }\end{array}$ & $\begin{array}{c}\text { EU Feed } \\
\text { to } \\
\text { Blending }\end{array}$ & $\begin{array}{l}\text { Blended } \\
\text { Feed to } \\
\text { Columns }\end{array}$ & $\begin{array}{l}\text { Loaded } \\
\text { Resin }\end{array}$ & $\begin{array}{c}\text { Dried } \\
\text { Resin to } \\
\text { Storagel } \\
\text { Calciner }\end{array}$ & $\begin{array}{l}\text { Calciner } \\
\text { Products }\end{array}$ & $\begin{array}{l}\text { Oxide to } \\
\text { Sintering }\end{array}$ \\
\hline $\mathrm{kg} /$ day & 17.81 & 49.38 & 1901.18 & 4283.81 & 6184.99 & 1481.40 & 208.11 & 2289.21 & 55.20 \\
\hline Batches/day & 5.00 & 5.00 & & & 10.12 & 10.12 & 20.24 & & \\
\hline $\mathrm{kg} / \mathrm{Batch}$ & 3.38 & 9.88 & & & 611.17 & 146.38 & 10.28 & & \\
\hline Liters/day & & 26.91 & 1875.00 & 4213.53 & 6088.53 & 1448.63 & 260.14 & & 9.72 \\
\hline \multicolumn{10}{|l|}{$\begin{array}{l}\text { Daily Mass } \\
\text { Balance, kg }\end{array}$} \\
\hline $\mathrm{UO}_{3}$ & 6.16 & & & & & & & & \\
\hline $\mathrm{U}_{3} \mathrm{O}_{8}$ & 11.65 & & & & & & & $\mathbf{5 7 . 5 0}$ & 55.20 \\
\hline $\mathrm{UO}_{2}\left(\mathrm{NO}_{3}\right)_{2}$ & & 24.92 & 24.92 & 55.99 & 80.91 & & & & \\
\hline $\mathrm{UO}_{2}(\operatorname{Resin})$ & & & & & & 55.30 & 55.30 & & \\
\hline Resin Solids & & & & & & 104.03 & 104.03 & & \\
\hline $\begin{array}{r}\text { Entrained } \\
\text { Water }\end{array}$ & & & & & & 153.13 & 31.21 & & \\
\hline Bound Water & & & & & & 17.50 & 17.50 & & \\
\hline HNO3 & & 5.69 & 9.40 & 39.82 & 49.22 & 2.31 & 0.07 & & \\
\hline \multicolumn{10}{|l|}{$\mathrm{H} 2 \mathrm{SO} 4$} \\
\hline Water & & 18.77 & 1866.86 & 4188.00 & 6054.86 & 1149.13 & & & \\
\hline Exhaust Gas & & & & & & & & 2231.71 & \\
\hline \multicolumn{10}{|l|}{$\mathrm{NOx}$} \\
\hline \multicolumn{10}{|l|}{$\begin{array}{r}\text { Total } \\
\text { Uranium }\end{array}$} \\
\hline --as UO3 & 5.13 & & & & & & & & \\
\hline --as U3O8 & 9.87 & & & & & & & 48.70 & 46.75 \\
\hline --Solution & & 15.00 & 15.00 & 33.70 & 48.70 & & & & \\
\hline --on Resin & & & & & & 48.70 & 48.70 & & \\
\hline
\end{tabular}




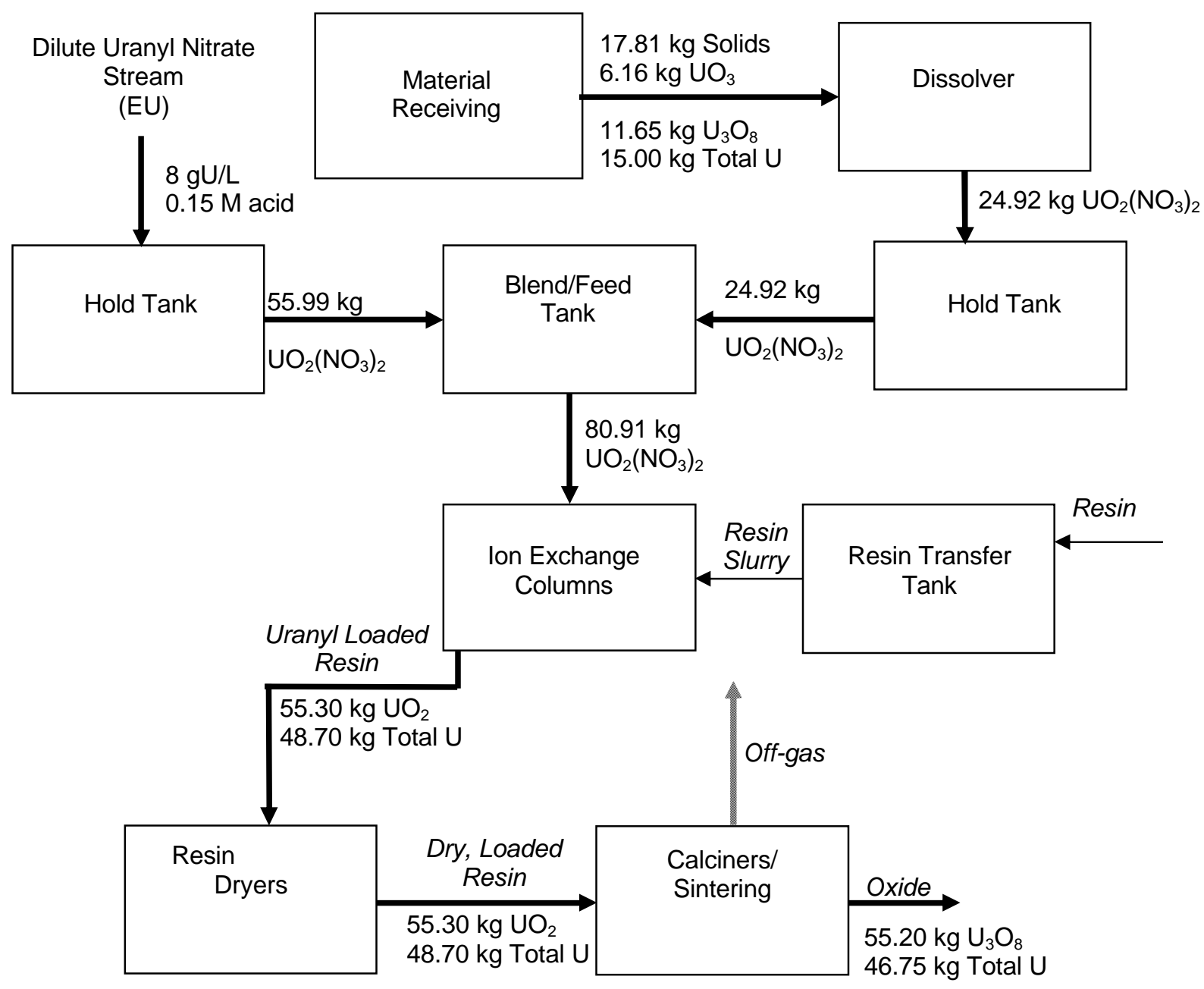

Figure 5 Uranium Process Throughput 


\subsection{ADDITIONAL PROCESS IMPROVEMENT CONSIDERATIONS}

The process development and demonstration were mature to insure process feasibility and viability. Several steps and operating conditions should be refined to optimize reliability and product consistency.

1. Resin transfer line pluggage: There is a potential for line pluggage. Further investigation of key resin slurry characteristics would be needed to assure operational, MC\&A, and criticality control are not adversely impacted by hold-up in the transfer lines.

2. Resin media selection:

Using a variety of other resins, some developed since initial studies were completed, the media selection needs to be optimized to maximize the loading of and specificity for uranium.

The use of spherical resin media that has been processed into granular form before use in the exchange columns needs to be further investigated. Resins currently only available in spherical form (which forms a less dense solid when calcined) could offer performance and cost advantages.

Dissolver and resin formulations can be adapted to allow a variety of feed source materials other than stock uranyl nitrate to be converted and recycled.

The addition of processes to pre-filter the feed stream for major impurities before and after exchange columns to both increase tolerance for a wide variety of feed stream composition as well as treatment of the stream after separation to minimize effluent environmental concerns.

3. Calciner operation conditions:

Optimization of resin media could reduce calciner treatment time

4. Waste treatment for off-gases:

Off-gases pose a difficulty in cases of incomplete combustion. Investigation of materials and technologies developed since initial process testing to determine if treatment of off-gases can be reduced. 


\subsection{SUMMARY AND RECOMMENDATIONS}

The Savannah River Site process development and Conceptual Design for the Onsite Uranium Recovery Facility demonstrated a viable process for large scale conversion of uranyl nitrate solutions to $\mathrm{U}_{3} \mathrm{O}_{8}$. The information in this report and, in detail in the references to this report, is sufficient to evaluate process alternatives.

Additional development activities are recommended for process/system refinement following a Functional Process Requirements for a new facility at Y-12. Section 3 of this report suggests several areas for refinement. 


\subsection{REFERENCES}

1 Technical Data Summary for ONSITE URANIUM RECYCLE by ION EXCHANGE AND

CALCINATION, DPSTD 84-107, A.E. Ofalt, J.L. Butler, J.S. Allender, W.C. Mosley, S.T. Augsburger, S.F. Peterson, and H.E. Shook, E.I. du Pont de Nemours \& Co., Savannah River Laboratory, August 1884.

2 Conceptual Design Report for Onsite Uranium Recycle Facility 200 Area Savannah River Plant, DPE 3728, Engineering Department - Design Division, E.I. du Pont de Nemours \& Co, Inc. Wilmington, DE, December 1983.

3 ONSITE URANIUM RECYCLE FACILITY, Basic Data Report for Current Appraisal for Budget, S.P. Rideout, P.E. England, G.H. Sykes, A.E. Ofalt, S.T. Augsburger, J.S. Allender, Budget Project 85-D-145, E.I. du Pont de Nemours \& Co, Inc, November 7, 1983.

4 ION EXCHANGE ONSITE URANIUM RECYCLE DEVELOPMENT: HYDRAULIC AND PNEUMATIC TRANSFER OF MACROPOROUS RESIN FOR BATCH OPERATIONS, A.E. Ofalt, Savannah River Laboratory, DPST-83-645, June 30, 1983.

5 ONSITE URANIUM RECYCLE PROTOTYPE DEVELOPMENT: MICROWAVE EQUIPMENT SPECIFICATIONS, A.E. Ofalt, Savannah River Laboratory, DPST-83-644, June 30, 1983.

6 FAVORABLE RESIN CALCINATION CONDITIONS IN THE ONSITE URANIUM RECYCLE PROCESS, M.K. Jones, A.S. Ferrara, Savannah River Laboratory, DPST-86-760, November 5, 1986. 
WSRC-TR-2005-00432, Rev. 0

CC: T.M. Adams, SRNL

R.L. Bickford, SRNL

G.T.Chandler, SRNL

L. B. $\{$ Penny $\}$ Cunningham, Y-12

A.J. Duncan, SRNL

D.J. Hathcock, SRNL

N.C. Iyer, SRNL

R. S. Johnson, Y-12

D. K. Little, Y-12

L.W. Little, Process Engineering Associates

G. L. Pfennigwerth, Y-12

J. K. Prazniak, Y-12

R.L. Sindelar, SRNL

L. H. Stinton, Y-12

S.L. West, SRNL 